\title{
A GENDER BASED STUDY OF HIVIAIDS RELATED KNOWLEDGE AND SEXUAL ATTITUDES IN STUDENTS FROM LADDAKH
}

\section{Sood S}

P.G. Department of Psychology, University of Jammu, Jammu, Jammu and Kashmir, India

\begin{abstract}
Introduction: A review of studies conducted on sexuality in India has revealed that premarital sex in youth is prevalent in 0-10 percent of women and 15-30 percent men and it is on rise. The young people indulge in risky behavior pattern such as infrequent or irregular contraceptive use. Youth is facing a significant risk of sexual health and lack in making informed sexual choice. The objective of this study is to explore the HIVIAIDS related knowledge and sexual attitudes held by young students from Laddakh
\end{abstract}

Methodology: Systematic sampling was used to collectdata from 100 Laddakhi students living in Jammu in the age range 18-29 years. The mean age of the sample was 22.28. Sexual Attitude Scale and HIV Related Knowledge Questionnaire were applied in this study.

Results: The results of test indicate significant gender differences in sexual attitudes. The male Laddakhi students held more favourable attitude towards pre marital sex, polygamy and pornography than their female counterparts. In comparison to male participants, the young female participants reflected favorable attitude towards establishing same sex relationships. The participants in the study also hold misconceptions about HIVIAIDS.

Conclusions: In addition to low level of awareness on HIVIAIDS, holding favorable sexual attitudes might result in involvement in risky sexual behavior. Organizing awareness campaigns at school level to focus the youth might be useful in curbing the potential involvement of young students in risky sexual behavior.

Key words: Gender difference, HIVIAIDS, Risky behavior, Sexual attitudes, Youth

\section{INTRODUCTION}

Sexual behavior is innateand based on drive, though modified by social factors. Cultural conditioning accounts for sexual expression. ${ }^{1}$ Indian culture based on rigid norms governing sexuality assumes that premarital sex is rare. However, increase in sexually transmitted infections, unintended teenage pregnancies and threat of HIVIAIDS draws our attention to explore the current trends in sexuality in India. A review of studies conducted on

\footnotetext{
Correspondence:

Dr. Sarita Sood

Assistant Professor

P.G. Department of Psychology,

University of Jammu, Jammu

Jammu and Kashmir, India.

Email: sarita.sood@yahoo.com
}

sexuality in India has revealed that premarital sex in youth is prevalent in 0-10 percent of women and 15-30 percent men ${ }^{2,3}$ and it is on rise. ${ }^{4,5}$ The young people indulge in risky behavior pattern such as infrequent or irregular contraceptive use. ${ }^{2}$ Youth is facing a significant risk of sexual health and lack in making informed sexual choice. ${ }^{6}$ A study conducted on youth in Mumbai revealed that young people had limited awareness of most of the sexual matters such as HIVIAIDS and safe sex practices. ${ }^{[7]}$ In depth awareness of HIVIAIDS is limited in youth though 91 percent of young men and 73 percent of young women had heard about it.?

Knowledge of HIVIAIDS and sexual attitudes among youth are of particular interest as the period between menarche and marriage is for many young people a time of sexual experimentation that may involve high-risk behaviours. ${ }^{8}$ The majority of people with HIVIAIDS can be associated with 
certain lifestyle risks. Gender differences are reflected in previous studies conducted to assess sexual attitudes and risky behavior. More than 60 percent college students from China approved of premarital sex showing favorable attitude of the youth. ${ }^{9}$ In a study on young female migrant workers in China, low level of sex-related knowledge has been demonstrated along with nearly $13 \%$ of participants holding favorable attitude towards premarital sexual intercourse. ${ }^{10}$ Gender differences were reported in sexual attitudes and behavior reflecting more liberal attitudes and more frequent behaviors among male participants than females. ${ }^{11}$ In a study conducted in China too, the males reflected more favorable attitude towards premarital sex. ${ }^{12}$ Similarly, in a literature review conducted on sexual attitudes, it was found that permissive sexual attitudes in men was higher than in women ${ }^{13}$ whereas conservative attitudes toward sexuality were reported to be more in women. ${ }^{14,15}$ In a survey on 265 college students, high HIV related knowledge was reported but gender differences became evident with larger number of males holding unfavorable sexual attitudes. ${ }^{16}$ Gender differences are evident in young people in North India with respect to more permissive attitudes for involvement of males in premarital sex, homosexual acts and extramarital sex. ${ }^{17}$ In a study on university students in Malawi no differences were evident ${ }^{18}$ Mixed results were reported in a study conducted in Nigeria on the University students having knowledge about transmission and symptomatology but some misconceptions about transmission were also reported. ${ }^{19}$ Similar findings were reported showing sound knowledge of HIV but with some misperceptions about transmission. ${ }^{20}$ Gender differences in knowledge about HIVIAIDS in young college going population in India were reported with boys having better knowledge than girls. ${ }^{21}$

In the light of findings from previous research, this study was designed to explore gender differences in HIV related knowledge and sexual attitudes of young students hailing from Laddakh region of the state of Jammu and Kashmir (India).The population in the age-group 15-29 years, referred to as 'Youth', as per National Youth Policy-2014 [22] is regarded as being the most vulnerable to HIVI AIDS. Additionally the people who stay away from their home or have migrated are likely to be at greater risk since the experiences of isolation and loneliness might elevate the risky behavior which in turn might account for vulnerability to HIVIAIDS. ${ }^{[23]}$ Therefore, the current study also aims to assess HIVIAIDS awareness in the young students who have moved away from their home and are staying elsewhere.

\section{METHODOLOGY}

Cross sectional design was followed for the collection of data. Using the systematic random sampling technique, the data was collected from the young students belonging to Laddakh region. The first participant in each area where the Laddakhi students stayed was selected randomly and thereafter, every tenth young Laddakhi student was selected. Only the students who were residing in Jammu city, away from their home, either in hostel or on rent (paid accommodation) were considered for the study. The consent of the participants was sought and the purpose of research was explained to them prior to administration of the tools. Confidentiality of the responses and personal information was assured. The young students unwilling to participate were not compelled. The collection of data was completed in ten days.

The tools used in the study were sexual Attitudes Scale ${ }^{24}$ measures attitudes in five areas of human sexuality namely premarital sex, polygamy, pornography, lesbianism (for women) and homosexuality (for men). Responses are marked on five point scale ranging from strongly agree to strongly disagree. The lower scores indicate unfavorable attitudes towards particular scale. HIV Related Knowledge Questionnaire ${ }^{25}$ adopted from Health Initiatives for Youth and the Measurement Group was employed. It comprises of eighteen statements with two options true and false. The participants were required to check out the appropriate option. The hypotheses were; there will be significant differences in sexual attitudes of young male and female Laddakhi students, there will be significant differences in HIV related knowledge of young male and female Laddakhi students and the young Laddakhi students will be having correct HIV related knowledge.

Regarding the sample; due to harsh weather conditions and inadequate facilities in Laddakh region, the young people move out of their home and approach the institutions about other regions to get proper education in the state Jammu and Kashmir. The sample chosen for the current study 
comprised of 100 Laddakhi students staying in Jammu of which 50 were male and 50 were female. These students had solely moved from their native place for seeking higher education. These students were from Leh or Kargil districts in Laddakh region of the state of Jammu and Kashmir (India). All the participants were either staying in rented or paying guest accommodation or hostel away from their own family. The age range of the sample was 18 to 29 years with the mean age 22.28 .

\section{RESULTS}

The data collected using the tools were coded and analyzed using SPSS version 20. Mean and S. D. were calculated and Independent Samples $t$ test was employed to obtain any significant gender differences. The frequencies and percentages were also obtained to assess the HIVIAIDS related knowledge held by the youth. The demographic details of the sample are presented in table 1.

\begin{tabular}{|l|l|c|}
\hline \multicolumn{3}{|l|}{ Table 1. Demographic characteristics of the sample } \\
\hline Variable & Category & $\mathbf{N}(\mathbf{1 0 0})$ \\
\hline \multirow{3}{*}{ Gender } & Male & 50 \\
\cline { 2 - 3 } & Female & 50 \\
\hline \multirow{2}{*}{ Age Range } & $18-23$ & 66 \\
\cline { 2 - 3 } & $24-29$ & 34 \\
\hline \multirow{2}{*}{ Religion } & Buddhist & 94 \\
\cline { 2 - 3 } & Muslim & 6 \\
\hline \multirow{3}{*}{ Education } & Senior Secondary & 67 \\
\cline { 2 - 3 } & Graduate & 12 \\
\cline { 2 - 3 } & Post Graduate & 21 \\
\hline $\begin{array}{l}\text { Place of } \\
\text { Residence }\end{array}$ & Hostel & 50 \\
\cline { 2 - 3 } & Rented Accommodation & 50 \\
\hline
\end{tabular}

Table 2. Gender Differences in Sexual Attitudes and HIV Related Knowledge in Young Laddakhi Students

\begin{tabular}{|c|c|c|c|c|c|c|}
\hline Variable & Sex & $\mathbf{N}$ & Mean & S.D. & $t$ & $P$ value \\
\hline \multirow{2}{*}{$\begin{array}{l}\text { Pre-marital } \\
\text { Sex }\end{array}$} & Male & 50 & 28.72 & 10.764 & \multirow{2}{*}{$3.883^{* *}$} & \multirow{2}{*}{0.000} \\
\hline & Female & 50 & 20.48 & 10.453 & & \\
\hline \multirow[t]{2}{*}{ Polygamy } & Male & 50 & 20.68 & 6.234 & \multirow{2}{*}{$3.161^{* *}$} & \multirow{2}{*}{0.002} \\
\hline & Female & 50 & 16.32 & 7.498 & & \\
\hline \multirow[t]{2}{*}{ Pornography } & Male & 50 & 29.96 & 5.491 & \multirow{2}{*}{$4.035^{\star *}$} & \multirow{2}{*}{0.000} \\
\hline & Female & 50 & 25.48 & 5.610 & & \\
\hline \multirow{2}{*}{$\begin{array}{l}\text { Lesbianism / } \\
\text { Homosexu- } \\
\text { ality }\end{array}$} & Male & 50 & 19.40 & 4.707 & \multirow[b]{2}{*}{$2.446^{*}$} & \multirow[b]{2}{*}{0.016} \\
\hline & Female & 50 & 22.94 & 9.087 & & \\
\hline \multirow{2}{*}{$\begin{array}{l}\text { Overall } \\
\text { Sexual } \\
\text { Attitudes }\end{array}$} & Male & 50 & 99.20 & 19.430 & \multirow[b]{2}{*}{$3.244^{* *}$} & \multirow[b]{2}{*}{0.002} \\
\hline & Female & 50 & 84.98 & 24.144 & & \\
\hline \multirow{2}{*}{$\begin{array}{l}\text { HIV Related } \\
\text { Knowledge }\end{array}$} & Male & 50 & 10.62 & 2.069 & \multirow{2}{*}{0.438} & \multirow{2}{*}{0.662} \\
\hline & Female & 50 & 10.80 & 2.040 & & \\
\hline
\end{tabular}

Gender differences in sexual attitudes and HIV related knowledge were analyzed through applying independent samples $t$ test. Results presented in Table 2 clearly reveal that there are no gender differences in HIV related knowledge. However, gender differences are apparent in sexual attitudes. On the three dimensions of sexual attitude scale namely, pre-marital sex, polygamy, and pornography, the male participants have shown favorable attitude. The overall score on sexual attitudes also is higher among males. This reflects that the study populationis more likely to involve in risky behaviors as they might be sexually active prior to matrimony. They might establish several sexual relationships or involve in sexual activities with more than one partner simultaneously. The viewing of erotic material is also likely to be higher in males. An opposite trend was noticed in case of attitude toward lesbianism and homosexuality. As compared to males, the female participants have shown favorable attitude only in establishing same sex relationships. These findings are in line with previous studies. ${ }^{12,13,14,15,16,21}$ see table 3 .

\begin{tabular}{|c|c|c|c|}
\hline Dimension & $\begin{array}{l}\text { Authors/ } \\
\text { Researchers }\end{array}$ & Year & Findings \\
\hline $\begin{array}{l}\text { Pre-marital } \\
\text { Sex }\end{array}$ & $\begin{array}{l}\text { - Wang B, Li } \\
\text { X, Stanton } \\
\text { B, et al. } \\
\text { - Bhugra D, } \\
\text { Mehra R, } \\
\text { deSilva, P } \\
\text { et al. }\end{array}$ & 2007 & $\begin{array}{l}\text { Favorable and } \\
\text { permissive } \\
\text { attitude for } \\
\text { males }\end{array}$ \\
\hline Polygamy & $\begin{array}{l}\text { - Bhugra D, } \\
\text { Mehra R, } \\
\text { deSilva, P } \\
\text { et al. }\end{array}$ & 2007 & $\begin{array}{l}\text { Permissive } \\
\text { attitude for } \\
\text { males }\end{array}$ \\
\hline $\begin{array}{l}\text { Lesbianism/ } \\
\text { homosexu- } \\
\text { ality }\end{array}$ & $\begin{array}{l}\text { - Bhugra D, } \\
\text { Mehra R, } \\
\text { deSilva, P } \\
\text { et al. }\end{array}$ & 2007 & $\begin{array}{l}\text { Permissive } \\
\text { attitude for } \\
\text { males }\end{array}$ \\
\hline $\begin{array}{l}\text { Overall } \\
\text { Sexual At- } \\
\text { titudes }\end{array}$ & $\begin{array}{l}\text { - Fugere M A, } \\
\text { Escoto C, } \\
\text { Cousins A J } \\
\text { et al. } \\
\text { - Askun D, } \\
\text { Ataca B. } \\
\text { - Jaya J, } \\
\text { Hindin M J. }\end{array}$ & $\begin{array}{l}2007 \\
2007\end{array}$ & $\begin{array}{l}\text { Unfavorable } \\
\text { attitudes held } \\
\text { by males; } \\
\text { Permissive } \\
\text { attitudes for } \\
\text { males and } \\
\text { conservative } \\
\text { attitudes for } \\
\text { females }\end{array}$ \\
\hline $\begin{array}{l}\text { HIV Related } \\
\text { Knowledge }\end{array}$ & $\begin{array}{l}\text { - Lal, SS, } \\
\text { Vasan, RS, } \\
\text { Sarma, PS } \\
\text { et al. }\end{array}$ & 2000 & $\begin{array}{l}\text { Better } \\
\text { knowledge in } \\
\text { males }\end{array}$ \\
\hline
\end{tabular}


The data were further subjected to assess the correct HIV related knowledge held by the participants. Percentage of the responses of the participants to each statement (item wise) was obtained. Table 4 shows HIV related knowledge in young Laddakhi students. On scrutinizing the data, it is revealed that the participants of the studyhold certain misconceptions. The correct response rate on most of the statements is not very high. It is important to assess HIV related knowledge as its understanding and promoting safe behavior. The item stating "Condoms reduce the risk of getting the AIDS virus" and "having sex without a condom increase a person's risk of getting HIV" reflects that majority of the participants know the importance of contraceptive use in HIV prevention.

The low level of awareness on certain statements (Table 4) along with holding favorable sexual attitudes might result in indulgence of the young students in risky sexual behavior. In particular, the males participating in current study seem to be at greater risk as they have more favorable sexual attitudes. The incorrect knowledge about the statement "A person must have lots of sexual partners to be at risk for HIV" shows propensity of indulging in risky behavior as it is well supported by favorable attitude or polygamous relationships.

\section{DISCUSSION}

The HIV/AIDS awareness campaigns at the state level need to be geared up for such population that falls in age range 18-29 years and are in such phase. The clear and relevant information may be even disseminated at the school level specially when they are at the verge of entering the adulthood and become sexually active. This would also be helpful as it will equip the young students with adequate knowledge before they actually move out of the home, away from their parents, into the setup where they might be on their own taking decisions by themselves.

The findings of this study may be replicated for future research with the larger sample. Moreover, the studies with different ethnic groups will help in establishing if there are similar trends in the young students from distinctive cultural backgrounds and if such issues need to be dealt in culturally specific manner.

Table 4. HIV Related Knowledge in the Study Population

\begin{tabular}{|c|l|c|c|}
\hline No. & \multicolumn{1}{|c|}{ HIV related knowledge } & Correct response & Incorrect response \\
\hline 1 & $\begin{array}{l}\text { Blood, Semen, Vaginal fluids, and breast milk are the only fluids that can } \\
\text { transmit HIV. }\end{array}$ & $84 \%$ & $16 \%$ \\
\hline 2 & Semen has higher concentration of HIV than blood. & $33 \%$ & $67 \%$ \\
\hline 3 & A hangnail is a potential route of HIV infection. & $68 \%$ & $32 \%$ \\
\hline 4 & HIV antibodies can take up to 10 years to show up. & $66 \%$ & $34 \%$ \\
\hline 5 & In confidential testing, name is associated with results. & $61 \%$ & $39 \%$ \\
\hline 6 & Most babies born to HIV positive mothers are not HIV positive. & $13 \%$ & $87 \%$ \\
\hline 7 & Mucous membranes in anus are more delicate than the membranes in mouth. & $61 \%$ & $39 \%$ \\
\hline 8 & $\begin{array}{l}\text { Keeping in good physical condition is the best way to prevent getting the } \\
\text { AIDS virus. }\end{array}$ & $48 \%$ & $52 \%$ \\
\hline 9 & A person can get AIDS by kissing and hugging someone. & $88 \%$ & $12 \%$ \\
\hline 10 & Condoms reduce the risk of getting the AIDS virus. & $97 \%$ & $3 \%$ \\
\hline 11 & Most people with the AIDS virus quickly show signs of being sick. & $44 \%$ & $56 \%$ \\
\hline 12 & Having sex without a condom increase a person's risk of getting HIV. & $97 \%$ & $3 \%$ \\
\hline 13 & A person must have lots of sexual partners to be at risk for HIV. & $7 \%$ & $93 \%$ \\
\hline 14 & $\begin{array}{l}\text { People who get the AIDS virus through needle sharing cannot spread the } \\
\text { virus during sex. }\end{array}$ & $78 \%$ & $22 \%$ \\
\hline 15 & There is a cure for HIV. & $62 \%$ & $38 \%$ \\
\hline 16 & Cleaning injection equipment with water is good way to kill HIV. & $70 \%$ & $30 \%$ \\
\hline 17 & You can get HIV from oral sex. & $22 \%$ & $78 \%$ \\
\hline 18 & $\begin{array}{l}\text { Keeping in good physical condition can prevent the development of AIDS } \\
\text { virus. }\end{array}$ & $58 \%$ & $42 \%$ \\
\hline
\end{tabular}




\section{REFERENCE}

1. Ford CS, Beach FA. Patterns of Sexual Behavior. New York: Harper \& Row, 1951.

2. Abraham L, Kumar KA. Sexual Experiences and their Correlates among College Students in Mumbai City, India. International Family Planning Perspectives 1999;25:139-46.

3. Jejeebhoy S. Adolescent Sexual and Reproductive Behaviour: A Review of the Evidence from India. In R. Ramasubban and S. Jejeebhoy, eds., Jaipur: Rawat Publications. Women's Reproductive Health in India 2000;40:101

4. Ghule M., Balaiah D. Correlates of Sexual Behavior of Rural College Youth in Maharastra, India. Eastern Journal of Medicine 2011;16:122-32.

5. Ghule M, Balaiah D \& Joshi B. Attitude towards Premarital Sex among Rural College Youth in Maharashtra, India. Sexuality and Culture 2007;11:1-17.

6. International Institute of Population Sciences (IIPS) and Population Council. Youth in India: Situation and needs study. Conducted by International Institute of Population Sciences and Population Council 2006. Available from http://www.popcouncil.org/ pdfs/IndiaUpdate/IndiaUpdate_YouthStudy.pdf [Last accessed on 2012 August 1].

7. International Institute of Population Sciences (IIPS) and Population Council. Youth in India: Situation and needs study 2006-2007. Mumbai: IIPS 2010. Available from http://www.popcouncil. org/pdfs/2010PGY_YouthInIndiaReport.pdf [Last accessed on 2012 August 1].

8. Parasuraman S, Kishor S, Singh, SK, Vaidehi Y. A Profile of Youth in India. National Family Health Survey (NFHS-3), India, Mumbai: International Institute for Population Sciences; Calverton, Maryland, USA: ICF Macro 2005-06, 2009

9. Huang K, Uba L. Premarital Sexual Behavior among Chinese College Students in the United States. Archives of Sexual Behavior 1992;21:22740.

10. Tang J, Xiaohui G, Yu Y, Ahmed et al. Sexual Knowledge, Attitudes and Behaviors among Unmarried Migrant Female Workers in China: A Comparative Analysis. BMC Public Health 2011;11:917.
11. Joshi PD. Indian Adolescent Sexuality: Sexual Knowledge, Attitudes and Behaviours among Urban Youth. Psychological Studies, 2010;.55:18187.

12. Wang B, Li X, Stanton B, et al. Sexual Attitudes, Pattern of Communication, and Sexual Behavior among Unmarried Out-of-school Youth in China. BMC Public Health 2007;7:189.

13. Fugere M A, Escoto C, Cousins A J, Riggs ML, Haerich P. Sexual Attitudes and Double Standards: A Literature Review Focusing on Participant Gender and Ethnic Background. Sexuality and Culture 2008;12:169-82.

14. Askun D, Ataca B. Sexuality Related Attitudes and Behaviors of Turkish University Students. Archives of Sexual Behavior 2007;36:741-52.

15. Jaya J, Hindin M J. Premarital Romantic Partnerships: Attitudes and Sexual Experiences of Youth in Delhi, India. International Perspectives on Sexual and Reproductive Health 2007;35:97-104.

16. Dekin B. Gender Differences in HIV-Related Knowledge, Attitudes, and Behaviours among College Students. American Journal of Preventive Medicine 1996;12:61-66.

17. Bhugra $D$, Mehra R, deSilva, $P$ et al. Sexual Attitudes and Practices in North India: A Qualitative Study. Sexual and Relationship Therapy 2007;22:83-90.

18. Natata PR, Muula AS, Siziya S,Kayambazinthu EE. Gender Differences in University Students' HIVIAIDS-Related Knowledge and Sexual Behaviours in Malawi: A pilot Study. Sahara Journal 2008;5:201-05.

19. Harding AK, Anadu EC, Gray LA, Champeau DA. Nigerian University Students' Knowledge, Perception, and Behaviours about HIV/AIDS: Are these Students at Risk? The Journal of Royal Society for the Promotion of Health1999;119:23-31.

20. de Beer I H, Gelderblom HC, Schellekens O, et al. University Students and HIV in Namibia: An HIV Prevalence Survey and a Knowledge and Attitude Survey. Journal of International AIDS Society 2012;15:9.

21. Lal, SS, Vasan, RS, Sarma, PS et al. Knowledge and Attitude of College Students in Kerala towards HIVIAIDS, Sexually Transmitted Diseases and Sexuality. The National Medical Journal of India 2000;13:231-236. 
22. National Youth Policy, Ministry of Youth Affairs \& Sports, Government of India - 2014.

23. Joint United Nations Programme on HIVIAIDS (UNAIDS)

24. Population Mobility and AIDS, UNAIDS Technical Update UNAIDS, Geneva, Switzerland 2001.
25. Abraham, A. Sexual attitude scale, National Psychological Corporation, Agra, India 1997.

26. Health Initiatives for Youth and the Measurement Group: HIV related knowledge questionnaire 1998. Available from http://www.themeasurementgroup. com/modules/hify_eye/hivknow.pdf [Last accessed on 2012 May 25]. 